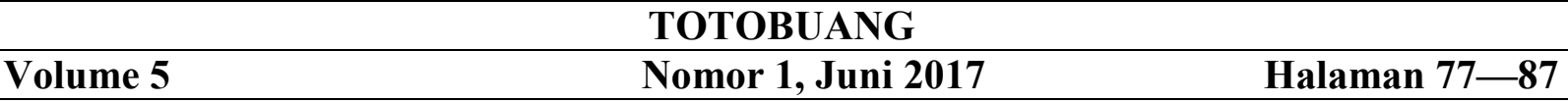

\title{
ANALISIS NILAI BUDAYA LEGENDA WAE SUSU MUJUALU DI NEGERI TEHUA (Analysis of Cultural Values Legend Wae Susu Mujualu in the Country Tehua)
}

\author{
Abdul Karim Tawaulu \\ Universitas Pendidikan Indonesia \\ Jl. Dr. Setiabudi Nomor 229 Bandung, fax. 022-2013651 \\ Pos-el: abdulkarimtawaulu@student.upi.edu
}

(Dikirim: 4 April 2017; Direvisi: 18 Mei 2017; Diterima: 2 Juni 2017)

\begin{abstract}
Oral literature in the midst of human civilization cannot be rejected because it is part of a social reality, especially for traditional communities. Social reality then turns into a set of bounded values and becomes local cognition of society that is called local wisdom. The perspective, the way of life and activity of traditional community is inseparable from those wisdom values. This study aims to reveal the cultural values that exist in Wae Susu Mujualu legend. Cultural value is the value omnipotence of God, honesty, human relationship with nature, and the value of responsibility. The method used in this research is descriptive qualitative analysis focusing on empirical data obtained in the field. To get accurate data hence researcher use interview technique, observation, and triangulation.
\end{abstract}

Keywords: oral literature, cultural value, Wae Susu Mujualu

\section{Abstrak}

Sastra lisan di tengah peradaban manusia tidak dapat ditolak karena iamenjadi bagian dari sebuah realitas sosial, apalagi bagi masyarakat tradisional.Realitas sosial itu kemudian berwujud menjadi tata nilai yang mengikat dan dijadikan sebagai pengetahuan lokal masyarakat pendukungnya yang disebut dengan kearifal lokal.Cara pandang, cara hidup, dan aktifitas hidup lainnya pada masyarakat tradisional tak dapat dilepaskan dari nilai-nilai kearifan itu.Penelitian ini bertujuan mengungkap nilai-nilai budaya yang terdapat di dalam legenda Wae Susu Mujualu dengan instrumen utamanya adalah peneliti sendiri.Nilai-nilai budaya itu adalah nilai kemahakuasaan Tuhan, nilai kejujuran, hubungan manusia dengan alam, dan nilai tanggungjawab.Metode yang digunakan dalam penelitian ini adalah deskriptif kualitatif yang memusatkan analisis pada data-data empiris yang diperoleh di lapangan.Untuk mendapatkan data yang akurat maka peneliti menggunakan teknik wawancara, observasi, dan triangulasi.

Kata-kata kunci: sastra lisan, nilai budaya, Wae Susu Mujualu.

\section{PENDAHULUAN}

Sastra lisan telah mengalami sejarah perkembangan yang cukup panjang yang sulit untuk dilacak dalam khazanah sastra Indonesia. Hal ini disebabkan oleh kurangnya peminat dan dokumentasi. Namun hal itu tidak mengurangi nilai-nilai budaya dan tradisi yang ada di daerahdaerah pendukungnya, sebab pada dasarnya sastra lisan merupakan satu kesatuan yang tak dapat dipisahkan dari komunitas masyarakat itu.

Dikatakan sastra lisan karena sastra tersebut disalurkan melalui mulut dan dari satu generasi ke generasi berikutnya tanpa ada suatu naskah tertulis. Jika sastra lisan itu telah ditulis tetapi esensinya sebagai sastra lisan tetap tidak luntur.

Sastra lisan merupakan bagian dari suatu kebudayaan yang tumbuh dan berkembang di tengah-tengah masyarakat dan diakui sebagai milik bersama, karena sastra lisan yang tumbuh dan berkembang itu merupakan pencerminan situasi, kondisi dan tata krama masyarakat pendukungnya. Pertumbuhan dan perkembangan sastra lisan itu merupakan pertumbuhan dan gerak dinamis pewarisnya dalam melestarikan nilai-nilai budaya leluhurnya.

Ratna (2011:92) menyatakan sastra dan masyarakat mempunyai hubungan dalam bentuk interaksi konseptual yang 
memberikan kemungkinan adanya fungsi untuk mengidentifikasi struktur-struktur sosial. Bahkan menurutnya karya sastra sebagai respons atas kehidupan sosial.

Dalam masyarakat yang sedang berkembang seperti masyarakat Indonesia saat ini, berbagai bentuk kebudayaan lama termasuk sastra lisan dapat dijadikan sebagai sarana komunikasi antar unsur-unsur kebudayaan yang ada.Fungsi sarana komunikasi inilah yang dianggap dapat mengekalkan keberadaan sastra lisan tersebut apalagi di tengah gempuran arus teknologi dan informasi yang semakin menggeliat.

Amir (2007:6) menyatakan bahwa dari berbagai genre (jenis) sastra lisan itu terlihat fenomena ada yang hidup marak, ada yang memudar, ada yang hampir punah, bahkan ada yang sudah punah.Kepunahan ini tentu menjadi bumerang bagi kelangsungan ekosistem adat, dan tradisi yang dimiliki oleh Indonesia selaku gudangnya "tambang" budaya Nusantara.

Sastra lisan ada dan hidup di tengah masyarakat. Masyarakat pemiliknya tetap menghargai, menghidupkan dan menghidupinya. Bahkan dalam masyarakat, sastra lisan mempunyai fungsi penting; tidak semata-mata sebagai hiburan tetapi yang lebih penting adalah sebagai sarana pendidikan, sebagai pusat komunikasi, dan pada beberapa hal juga untuk ajang kompetisi status sosial pemakainya. Sastra lisan juga berfungsi sebagai pengikat identitas solidaritas bahkan lebih luas lagi sastra lisan digunakan sebagai salah satu cara kampanye politik.

Sastra lisan mengandung ide-ide transeden yang selalu bermuara pada pola kehidupan masyarakat pemiliknya.Ide-ide tersebut bahkan diyakini sebagai sebuah referensi dalam bersosial, berkomunikasi, menyatukan persepsi dan pandangan, juga sebagai ajang peleburan segmen-segmen sosial yang mungkin terdikotomi.

Belakangan ini aktivitas sastra oleh pegiat sastra lisan mengambil peran penting dalam menegosiasikan kepentingankepentingan sosial yang sifatnya pluralistik. Pertunjukan sastra lisan di khalayak ramai sudah tidak lagi berada pada area estetik tapi jauh melampauhi itu; sastra lisan telah mengeksiskan perannya sebagai wadah rekonsiliasi konflik horizontal. Nilai-nilai kearifan lokal yang mengitarinya dapat menjadi jembatan penghubung antar golongan, kelas sosial, dan agama.

Kearifan lokal berperan sebagai peneguhan akan nilai-nilai agama yang dianut oleh masyarakat. Dalam konteks masyarakat Maluku yang ethnic culture selalu kita dapati praktek agama yang berbarengan dengan praktek adat, tradisi. Ini tidak salah karena itulah kemestaan agama yang mengakui sekaligus mengayomi budaya yang merupakan hasil "ijtihad" manusia sebagai makhluk berperadaban.

Sastra lisan dan masyarakat tradisional seperti masyarakat Tehua selalu berkelindan bahkan tak dapat dihindari bahwa ternyata sastra lisan adalah bagian integral yang selalu mewarnai sejarah kehidupan masyarakatnya. Legenda Wae Susu Mujualu (WSM) adalah salah satu genre sastra lisan yang termasuk warisan budaya atau dapat dikatakan sebagai oral culture-nya masyarakat Tehua.Legenda ini menjadi perbedaharaan kehidupan rohani bagi masyarakat. Batu yang menjadi bukti adanya legenda tersebut dipercaya oleh masyarakat Tehua mempunyai kekuatan magis yang sulit ditembus dengan akal sehat atau logika. Masyarakat Tehua percaya kekuatankekuatan magis itu dapat membawa dampak positif dalam kehidupan mereka jika diperlakukan dengan baik, sebaliknya akanmembawa dampak buruk jika terjadi pelanggaran di lokasi keberadaan legenda itu. Keyakinan akan kekuatan magis ini terpola menjadi nilai-nilai yang terus tumbuh dan teraktualisasi dalam keseharian hidup masyarakat.

Dalam setiap pembahasan mengenai sastra lisan dengan berbagai genrenya, tentu memiliki fungsi bagi masyarakat 
pendukungnya. Fungsi legenda(WSM) bagi masyarakat negeri Tehua sangat banyak. Diantara fungsi-fungsi itu yakni sebagai:

a. Perekatan hubungan kekerabatan antarmasyarakat. Faktor ini muncul karena legenda ini sering menjadi bahan pengisi waktu luang;

b. Sarana untuk memperkuat hubungan kekeluargaan antara anak dengan orang tua. Hal ini terjadi karena cerita ini sering dijadikan sebagai bahan pengantar tidur atau meninabobokkan anak dan pengisi waktu berkumpul keluarga;

c. Sarana hiburan bagi anak-anak. Pendeknya cerita ini dapat menjadi penghibur bagi anak-anak yang rewel;

d. Sarana pendidikan. Selain ketiga fungsi di atas, cerita ini dapat dijadikan sebagai media yang dapat digunakan untuk memberikan pendidikan moraldan menanamkan nilai-nilai budaya padaanak, misalnya nilai kejujuran, nilai tanggungjawab, sikap taat kepada Tuhan dan sikap menghargai ciptaan-Nya.

Disamping keempat fungsi di atas, legenda WSM juga memberikan pengaruh terhadap hubungan sosial masyarakat Tehua. Sikap sosial ini tercermin dalam ungkapan "Sei hale hatu, hatu lepe'ei, sei hale sou, sou lepe'ei" (siapa yang balik batu, maka dia akan tertindas batu itu, siapa yang memutarbalikkan bahasa maka dia akan tertindas oleh bahasanya sendiri). Ungkapan ini mengandung pesan filosofi bahwa dalam kehidupan hendaklah mengedepankan sikap jujur dan benar dalam berkata karena lisan yang tak jujur hanya membawa mala petaka. Ungkapan ini sejalan dengan sebuah pepatah klasik yang berbunyi, "mulutmu harimaumu".

Berdasarkan pemaparan di atas, rumusan masalah yang dapat penulis kemukakan adalah nilai-nilai budaya apa saja yang terdapat dalam legenda WaeSusuMujualu?
Adapun tujuan penelitian ini adalahuntuk mendeskripsikan nilai-nilai budaya yang terdapat di dalam legenda Wae Susu Mujualu.

\section{LANDASAN TEORI}

Sastra lisan merupakan salah satu cabang kesenian dan sarana komunikasi atau ekspresi bahasa yang memainkan peranan penting dalam masyarakat tradisional. Sastra lisan di tengah peradaban manusia tak dapat ditolak bahkan sebaliknya harus diterima sebagai salah satu realitas sosial(Taum, 2011:7).

Menurut Hutomo (1991:1) istilah sastra lisan di dalam bahasa Indonesia, merupakan terjemahan bahasa Inggris, yaitu oral literature. Ada juga yang mengatakan istilah tersebut berasal dari bahasa Belanda; oraleletterknde. Kedua pendapat ini dapat dibenarkan, tetapi yang menjadi permasalahan adalah bahwa istilah ini dalam dirinya sebenarnya mengandung kontradiksi sebab frasa literature atau letterknde dalam bahasa Indonesia disebut sastra, susastra, atau kesusastraan yang mana istilah-istilah ini mengacu pada pengertian "tulisan" atau "buku". Namun terlepas dari kontradiksi ini, beliau mengatakan bahwa intinya sastra lisan adalah bentuk kesusastraan yang mencakup ekspresi kesusastraan warga suatu kebudayaan yang disebarkan dan diwariskan secara lisan. Sastra lisan hidup di tengahtengah masyarakat zaman dulu yang belum mengenal aksara atau tulisan.Ia melanjutkan merupakan, sastra lisan merupakan ekspresi masyarakat lampau dengan menggunakan media bahasa lisan, menurutnya yang dinamakan sastra lisan sebenarnya adalah kesusastraan yang mencakup ekspresi kesusastraan warga suatu kebudayaan yang disebarkan dan diturunkan secara lisan atau dari mulut ke mulut.

Sastra lisan bahkan merupakan cabang besar dari suatu kebudayaan lisan. Sastra lisan menunjuk pada suatu cara berpikir secara lisan dengan logika dan sistem penyampaian informasi tersendiri. Budaya 
lisan yang dimaksud berupah tradisi lisan. Puisi rakyat, mantra, pantun, gurindam, dan nyanyian rakyat termasuk di dalamnya. (Salleh, 1995, hlm. 24)

Purwadi (2009:1) menyatakan bahwa sastra lisan adalah hasil kolektif sebuah bangsa yang disebarkan dalam bentuk lisan maupun gerak isyarat, sehingga tetap berkesinambungan dari generasi ke generasi.

Sastra Lisan menurut Whellwright (dalam Taum, 2011, hlm. 8-9) adalah kreasi estetik dari imajinasi manusia. Menurutnya, para penutur sastra lisan itu tak ubahnya dengan novelis-novelis atau penyair-penyair yang menyusun cerita panjang dengan imajinasi dan sesivitas khusus yang kompleks, yang muncul dari rangsangan yang hebat antara permainan kekuatan alam dan manusia. Sastra lisan itu memiliki makna-makna semantis yang diaforik, yaitu elemen-elemen sastra lisan itu memiliki petunjuk yang tinggi dan memiliki kecocokan emotif dengan adat, suku-suku yang terumuskan dalam tradisi suku-suku tersebut. Sastra lisan berfungsi sebagai hikmat tradisional yang mengandung konvensi, sistem nilai, adat istiadat dan berbagai norma yang berlaku dalam masyarakat, bahkan menurut Vansina (dalam Taum, 2011, hlm. 10) sastra lisan ibarat kata-kata mutiara yang menjadi kunci memahami filosofi kerja, cinta, dan penderitaan leluhur kita di masa lampau.

Vansina (dalam Taum, 2011:10) mengemukakan bahwa sastra lisan adalah bagian dari tradisi lisan (oral tradition) atau biasanya dikembangkan dalam kebudayaan lisan berupah pesan-pesan, cerita-cerita atau kesaksian-kesaksian atau pun diwariskan secara lisan dari satu generasike generasi berikutnya.

Sastra lisan merupakan salah satu mentifact (fakta kejiwaan), yakni fakta yang terjadi dalam jiwa, pikiran, atau kesadaran manusia yang dituturkan dan diwariskan melalui bahasa lisan. Melalui bahasa lisan itu manusia membangun kesadaran dirinya dan seluruh tingkah lakunya dan menciptakan ruang gerak yang amat luas bagi dirinya. Dengan kata lain sastra lisan dan kesadaran berhubungan dengan bahasa sebagai mekanisme yang mengatur tingkah laku kemanusiaan dalam pengalaman hidup bermasyarakat (Taum, 2011:11).

Amir (2013:19) berpendapat bahwa sastra lisan itu hidup di masyarakat pertamanya, yaitu masyarakat yang melahirkan dan menghidupkannya, di daerah kelahiran, di kampung asal.

Sastra lisan adalah berbagai tuturan verbal yang memiliki ciri-ciri sebagai karya sastra pada umumnya yang meliputi prosa, puisi, nyanyian, dan drama lisan. Sebagai karya sastra menurut (Taum, 2011, hlm. 10) sastra lisan pun memenuhi ciri dulce et utile; indah dan bermanfaat. Penggunaan bahasa dan struktur dan pembaitannya indah (dulce) dan bermanfaat (utile) antara lain sebagai sarana pewarisan nilai, legitimasi kedudukan sosial-politik, ataupun sekadar melipur lara para pendengarnya.

Sastra lisan menurut Endraswara (2008:151) adalah karya sastra yang penyebarannya disampaikan dari mulut ke mulut secara turun-temurun. Ciri sastra lisan itu biasanya lahir dari masyarakat polos, belum melek huruf, bersifat tradisional, menggambarkan budaya milik kolektif tertentu yang tidak jelas siapa penciptanya, lebih menekankan pada aspek khayalan, ada sindiran, jenaka, dan sering melukiskan tradisi kolektif tersebut.

Mengenai ciri-ciri sastra lisan, menurut Supratno (2010:1) disebarkan secara lisan, diwarisi oleh generasi secara turun-temurun, bersifat anonim, memiliki sifat khas yang berbeda dari tradisi lisan, milik suku bangsa tertentu, dan menjadi salah satu identitas suku bangsa tertentu.

Sastra lisan menurut Brunvand (dalam Danandjaja, 2002:21) dapat dirincikan dalam enam kelompok, yaitu bahasa rakyat, ungkapan tradisional, pertanyaan tradisional, puisi rakyat, nyanyian rakyat, dan cerita rakyat. 
Cerita rakyat dibentuk oleh dua kata yakni "cerita" dan "rakyat" maka hasilnya adalah cerita milik rakyat, cerita tentang rakyat, cerita yang dituturkan oleh rakyat, atau cerita yang dibuat oleh rakyat. Jika dimaknai dari tinjauan teori sastra, terminologi cerita rakyat tidak dapat dilepaskan dengan budaya, sastra, dan sejarah suatu bangsa. Cerita rakyat merupakan bagian dari hasil kebudayaan masyarakat pendukung suatu kebudayaan kolektif yang diwariskan secara turun temurun secara tradisional atau secara lisan, sehingga menimbulkan versi-versi cerita yang berbeda, baik secara lisan maupun sebagian lisan yang disertai dengan alat bantu pengingat (Danandjaja, 2002:4).

Hutomo

(1991,hlm.67--70)

mengemukakan setiap genre sastra yang berkembang di masyarakat memiliki fungsi. Fungsi-fungsi tersebut, yaitu berkaitan dengan saling dengan adanya saling ketergantungan, secara utuh dan berstruktur, antara unsur-unsur sastra tulis atau lisan, baik di dalam diri sastra itu sendiri, maupun dengan lingkungannya. Fungsi sastra lisan bagi masyarakat yaitu (a) sebagai sistem proyeksi; (b) untuk pengesahan kebudayaan; (c) sebagai alat pemaksa berlakunya normanorma sosial dan sebagai alat pengendali sosial; dan (d) sebagai alat pendidikan.

Menurut Amir (2013, hlm. 34-40), fungsi sastra lisan adalah (a) sebagai bahan hiburan, yakni sastra lisan mengandung unsur-unsur estetis; (b) sebagai media pembawa ilmu, yakni sastra lisan membuka peluang komunikasi sosial antarmasyarakat dan menjadi pengetahuan bagi masyarakat; (d) sebagai penyimpan kosa kata puitika, yakni sastra lisan memuat kosa kata yang estetis dan khas: (c) sebagai sarana atau media pendidikan, yakni karya sastra yang berfungsi sebagai media sosialisasi nilainilai. Endraswara (2009, hlm. 175) mengungkapkan bahwa tradisi memiliki fungsi penting bagi keberlangsungan hidup.

Fungsi sastra lisan tak lepaskan dari nilai-nilai budaya yang mengelilinginya sehingga kehadiran sastra lisan bagi masyarakat pendukungnya tidak sekadar sebagai sarana hiburan saja akan tetapi sebagai perbendaharaan nilai. Kadang dalam melakukan komunikasi masyarakat menggunakan sastra lisan sebagai media penyampaian gagasan, dan ide.Sehingga dalam tataran ini lubang-lubang komunikasi yang tersumbat akibat ego, konflik, bahkan kepentingan politik dalam masyarakat dapat didobrak.

Selanjutnya, Danandjaja (2002:4) mengemukakan, cerita rakyat mempunyai ciri-ciri, yaitu, Penyebaran dan pewarisannya dilakukan secara lisan (pewarisannya secara turun temurun), Bersifat tradisional (hidup dalam suatu kebudayaan dan dalam kurun waktu kurang dari tiga generasi), Bersifat anonim (biasanya nama penciptanya sudah tidak diketahui lagi), Mempunyai fungsi tertentu dalam masyarakat (sebagai pelipur lara, pendidikan, dan bentuk protes sosial), Bersifat pralogis (mempunyai logika tersendiri), Pada umumnya bersifat sederhana, spontan, polos, dan seadanya, Terdapat versi-versi yang berbeda, Mempunyai fungsi dalam kolektif, dan Menjadi milik bersama.

Menurut Bascom (dalam Danandjaja, 2002:50) cerita rakyat terbagi dalam tiga golongan, yaitu (1) mite, (2) dongeng, dan (3) legenda.

Legenda adalah prosa rakyat yang mempunyai ciri-ciri yang mirip dengan mite, yaitu dianggap benar-benar terjadi tetapi tidak dianggap suci, ditokohi oleh manusia, walaupun ada kalanya mempunyai sifat luar biasa dan sering juga dibantu oleh makhlukmakhluk gaib, tempat terjadinya adalah dunia seperti yang kita kenal ini, dan waktu terjadinya belum begitu lampau (Bascom dalam Hutomo, 1991:64)

Legenda menurut Danandjaja (2002:5) adalah suatu cerita yang dianggap benar oleh masyarakat. Kebenaran itu dianggap sebagai kebenaran dari segi sejarah atau kepercayaan semata. Legenda merupakan sejarah rakyat 
karena legenda mempunyai latar belakang sejarah. Fokus legenda adalah tokoh tertentu, pada suatu sejarah tertentu dalam masyarakat.

Sejalan dengan Danandjaja, Endraswara (2005: 164) mengemukakan bahwa legenda merupakan cerita asal-usul suatu tempat dengan ditandainya tokoh makhluk superior. Legenda sering memunculkan figur istimewa, namun tidak dianggap keramat.

Brunvand (dalam Danandjaja, 2002:67-68) menggolongkan legenda menjadi empat, yaitu (1) legenda keagamaan, (2) legenda alam gaib, (3) legenda perseorangan, dan (4) legenda setempat.

(1) Legenda keagamaan adalah legenda yang di dalamnya diceritakan mengenai orang-orang suci, para wali dalam menyebarkan agama Islam, mengenai kepercayaan, mengenai kemukjizatan, wahyu, mengenai sembahyang dan mengenai kitab suci;

(2) Legenda alam gaib yakni cerita legenda yang biasanya berbentuk kisah yang dianggap benar-benar terjadi dan pernah dialami seseorang. Fungsi legenda semacam ini adalah untuk meneguhkan kebenaran takhyul atau kepercayaan;

(3) Legenda perseorangan adalah cerita legenda mengenai tokoh-tokoh tertentu yang dianggap oleh empunya cerita benar-benar pernah terjadi; dan

(4) Legenda setempat adalah cerita yang erat hubungannya dengan suatu tempat, nama daerah, dan bentuk topografi.

Setiap sastra termasuk juga sastra lisan, tentu mengandung nilai-nilai budaya bagi masyarakat pendukungnya. Nilai budaya merupakan nilai-nilai yang disepakati dan tertanam dalam suatu masyarakat, lingkup organisasi, lingkungan masyarakat yang mengakar pada suatu kebiasaan, kepercayaan (believe), simbol-simbol, dengan karakteristik tertentu yang dapat dibedakan suatu lainnya sebagai acuan perilaku dan tanggapan atas apa yang akan terjadi atau sedang terjadi.Nilai budaya adalah konsep-konsep mengenai yang hidup dalam alam pikiran sebagian besar masyarakat mengenai apa yang mereka anggap bernilai, berharga dan penting dalam hidupnya yang berfungsi sebagai suatu pedoman yang dapat memberi arah dan orientasi kepada kehidupan masyarakat miliknya (Koentjaraningrat dalam Supratno, 2010:2).

Koentjaraningrat

(2002:11) mengemukakan bahwa nilai-nilai budaya yang terkandung dalam bentuk-bentuk sastra adalah nilai budaya yang diangkat dari unsur-unsur kebudayaan yang universal yang sekalian isi dari semua kebudayaan, yaitu sistem religi dan keagamaan, sistem organisasi kemasyarakatan, sistem pengetahuan, bahasa, kesenian, sistem mata pencaharian hidup, dan sistem teknologi.

Lanjut Koentjaraningrat (2002:13) nilai budaya dalam masyarakat terkait dengan konsep abstrak yang telah dipelajari oleh individu sejak awal kehidupan, yakni sejak dalam proses sosialnya sebagai balita. Oleh karena itu, nilai budaya yang bersifat abstrak itu mempunyai fungsi sebagai pedoman tertinggi bagi kelakuan masyarakat.

Supratno

(2010:3-4) menambahkan,nilai budaya pada umumnya berfungsi sebagai pedoman hidup bagi manusia dalam masyarakat.Setiap masyarakat pada umumnya mempunyai nilai budaya yang saling berkaitan sehingga membentuk suatu sistem yang dapat menjadi pedoman hidup dan memberikan dorongan yang kuat bagi arah kehidupan masyarakat. Menurutnya nilai-nilai budaya adalah perekat yang sangat kuat untuk mempersatukan suatu bangsa.

Menurut Amir (1991:37-38) nilai budaya dalam hubungannya dengan manusia sebagai individu tampak pada nilai keberanian, kepahlawanan, kepemimpinan, dan keselarasan. Nilai budaya pada bagian manusia dengan masyarakat tampak pada nilai gotong royong, rela berkorban demi orang lain, dan sikap mendahulukan kepentingan orang lain. Nilai budaya pada 
bagian manusia dengan alam tampak pada sikap melestarikan alam, dan nilai budaya yang berkaitan dengan hubungan manusia dan Tuhan tampak pada kemanunggalan manusia dengan Tuhan.

Nilai-nilai budaya itu memiliki kedudukan sentral di tengah masyarakat. Sehubungan dengan kedudukan nilai budaya bagi kehidupan manusia dalam budaya apapun, baik sebagai pribadi maupun sebagai kelompok sosial, maka Saryono(1997:115-116), berpendapat bahwa nilai budaya mempunyai lima kedudukan, yaitu (1) sebagai penggerak ucapan, tindakan, perbuatan, dan perilaku manusia atau kelompok manusia, (2) sebagai pengendali ucapan, tindakan, perbuatan, dan perilaku manusia agar tidak dianggap sesat dan menyimpang dari norma, aturan, dan hukum yang berlaku di masyarakat, (3) sebagai proyeksi tujuan, harapan, cita-cita hidup manusia, (4) sebagai tolok ukur ucapan, tindakan, perbuatan manusia sebagai makhluk pribadi sosial dan sebagai hamba dari Khaliknya, (5) sebagai rujukan (acuan) ucapan, tindakan, perbuatan, dan perilaku manusia sebagai makhluk pribadi, sosial, dan sebagai hamba Khaliknya.

Menurut Supratno (2010:2), nilai-nilai budaya yang ada dalam tradisi lisan dapat diaktualisasikan atau diimplementasikan dalam kehidupan sehari-hari dan dijadikan sebagai pedoman atau model dalam hidup berkeluarga, bermasyarakat, berbangsa, dan bernegara.

\section{METODE}

Penelitian yang digunakan dalam penelitian ini adalah jenis penelitian kualitatif deskriptif yang memusatkan analisis pada data-data empiris. Dalam menganalisis data, dilakukan analisis penelitian lapangan, yaitu, menggunakan lingkungan alamiah sebagai sumber data langsung, sifatnya deskriptif analitik, lebih mengutamakan makna, tidak mengandalkan angka-angka tetapi lebih pada kedalaman penghayatan terhadap interaksi antarkonsep yang sedang dikaji (Endraswara, 2008:5).

Untuk mendapatkan data yang akurat tentang legenda WSM, penulis menggunakan teknik pengumpulan data yang ditawarkan oleh Sugiono (2011: 383) berupa teknik wawancara, teknik observasi, dan teknik triangulasi, dan teknik pencatatan lapangan. Teknik yang ada penulis gunakan ini juga untuk menganalisis nilai-nilai budaya yang terdapat dalam legenda tersebut.

\section{PEMBAHASAN}

Sastra lisan merupakan identitas suatu masyarakat.Kesusastraan suatu masyarakat adalah rekaman pikiran, renungan dan gagasan atau nilai-nilai pada masyarakat pada waktu tertentu. Gagasan atau nilai-nilai itu menjadi landasan perilaku dan sikap bagi masyarakat pendukungnya. Nilai-nilai itu bahkan menjadi pedoman dalam melakukan kegiatan dalam kehidupan. Sikap dan perilaku-perilaku itu bisa terwujud dalam bentuk do'a, mantra, upacara-upacara adat, kegiatan keagamaan, dan bentuk perilaku budaya lainnya.

Bagi masyarakat Tehua, legenda WSM merupakan identitas budaya. Legenda ini sudah menjadi ciri khas. Ciri khas itu tercermin dalam nilai-nilai kearifan lokal yang terdapat dalamnya.

\section{Ringkasan Cerita}

Pada zaman dulu ada tiga pasang mudamudi yang sedang kasmaran pergi ke hutan untuk mencari buah kenari.Mereka menyusuri tiap hutan di mana pohon kenari tumbuh, hingga sampailah di sebuah hutan yang bernama Pelelau. Di hutan ini banyak tumbuh pohon kenari. Mereka terus mencari buahnya dengan riangnya sambil sekali-kali bercanda. Merasa telah cukup hasil pencarian, mereka pun bergegas untuk meninggalkan hutan itu. Tujuan mereka adalah sungai Yahe. Di sungai itu buah kenari yang mereka dapat akanditumbuk sebelum pulang ke kampung. Setelah sampai 
di sungai Yahe mereka pun memilih tempat secara berpasang-pasangan untuk menumbuk buah-buah kenari itu. Diantara tiga pasangan ini, ada sepasang kekasih yang memilih tempat agak jauh dari dua pasangan yang lain. Tampaknya mereka asyik sekali menumbuk buah kenari.Sepasang kekasih yang terpisah tempat itu dengan asyiknya mereka menumbuk sambil diselingi dengan candaan. Sedang asyik-asyiknya bercanda, tiba-tiba sipemuda mencium bau kentut. Sambil memencet hidungnya, sipemuda itu menuduh kekasihnya, namun kekasihnya itu mengelak

Terjadilah perdebatan antara mereka berdua. Pada saat mereka sedang berdebat tiba-tiba dihadapan mereka lewat seekor ular bermata buta, tanpa pikir panjang keduanya berkata bahwa ular itu yang kentut.

Tiba-tiba tempat itu berubah gelap.Kabut menutupi tempat itu. Hujan turun lebat, guntur, kilat bergemuruh, angin kencang menerpa pepohonan hingga roboh ke tanah. Seakan-akan alam murka atas perkataan mereka. Rupanya ular itu adalah jelmaan leluhur penunggu sungai itu. Sejurus kemudian, tiba-tiba hujan, guntur, dan kilat, berhenti.Alam menjadi terang kembali, tetapi ada yang aneh setelah itu.Pemuda dan gadis itu tidak kelihatan. Muncul ditempat itu batu besar yang menyerupai manusia.Ternyata kedua manusia itu telah berubah menjadi batu. Payudara gadis itu menyembul keluar. Teman-teman mereka heran, bingung dan takut. Mengapa sampai bisa begini? Nasi sudah menjadi bubur, tak ada guna lagi untuk disesali. Mereka pun bergegas pulang ke kampung untuk melaporkan kejadian ini kepada Ayalu (Raja). Setelah mendapat laporan, Ayalu kemudian memerintahkan masyarakat untuk pergi ke tempat kejadian. Dengan berbekal linggis, parang, kapak, dan peralatan lainnya, masyarakat berusaha membongkar batu itu. Akan tetapi usaha mereka sia-sia saja.Tubuh kedua anak manusia tersebut telah dibungkus oleh batu. Akhirnya Ayalu memerintahkan masyarakatnya untuk kembali pulang. Orang tua dari kedua anak itu terpukul dan sedih menyaksikan nasib yang menimpa anak-anak mereka.

\section{Asal Usul NamaWae Susu Mujualu (WSM)}

Secara etimologi, Wae Susu Mujualu adalah bentukan dari tiga kata, yakni wae, susu, dan mujualu. Ketiga frasa ini merupakan pencampuran bahasa Melayu Ambon dan bahasa daerah Telutih yang digunakan masyarakat negeriTehua. "Wae" artinya air atau sungai, "susu" pengertiannya lebih kepada bentuk nomina yaitu payu darah, dan "mujualu" artinya perempuan remaja. Frasa mujualu sendiri asal katanya dari frasa mujua yang berarti keponakan perempuan. Sehingga pengertian Wae Susu Mujualu adalah air yang keluar dari sela-sela batu yang berbentuk payu darah.

Dalam sejarahnya pemberian nama WSM sifatnya anonim, karena sampai saat ini tak diketahui siapa yang memberikan nama itu. Keberadaannya terjadi secara alamiah. Ini sejalan dengan ciri sastra lisan itu sendiri.

Berdasarkan pengelompokannya, WSM termasuk ke dalam legenda setempat karena cerita ini berhubungan dengan nama sebuah lokasi/nama sungai di negeri Tehua kecamatan Telutih.

\section{Deskripsi Nilai-Nilai Budaya}

Nilai-nilai budaya yang terdapat di dalam legenda WSM adalah nilai kemahakuasaan Tuhan, nilai kejujuran, nilai hubungan manusia dengan alam, dan nilai tanggung jawab.

\subsection{Nilai Kemahakuasaan Tuhan}

Cerita legenda WSM memberikan pesan kepada masyarakat Tehua bahwa fenomena alam terjadi merupakan tanda dari Tuhan. Kekuasan itu ditunjukkan kepada manusia agar mau menjaga dan melestarikan alam demi kelangsungan hidup anak cucu di kemudian hari. 
Nilai tersebut dapat diaktualisasikan dalam kehidupan masyarakat Tehua, yaknipercaya bahwa segala yang terjadi di dunia akan kehendak dan kuasa Tuhan.

Alam dengan karakternya itu, membuat sebagian masyarakat tradisional di Indonesia meyakini bahwa alam dengan segala yang ada di dalamnya memiliki "tuan". Masyarakat percaya bahwa ada makhluk lain yang diberi tanggung jawab oleh Tuhan untuk menjaga kelangsungan ekosistem alam ini. Makhluk itu berada di alam yang tak nyata. Menurut keyakinan masyarakat, makhluk itu adalah para leluhur atau bangsa Jin yang diberi tugas. Menurut mereka makhluk-makhluk itu merupakan representasi kekuasaan Tuhan.

\subsection{Nilai Kejujuran}

Sikap jujur dan tidak berdusta merupakan sikap mulia yang harus dimiliki oleh setiap orang, begitu pun juga oleh masyarakat Tehua. Nilai-nilai kejujuran merupakan value of life (nilai kehidupan).

Di tengah pesatnya arus globalisasi saat ini, nilai-nilai kejujuran yang harusnya menjadi nilai penting dalam hidup seakan telah menjadi barang yang langka.Kejujuran tidak lagi dipandang sebagai sikap hidup yang baik, melainkan hanya sebagai sebuah kamu flase saja. Padahal kejujuran merupakan dasar pijak dari sebuah proses komunikasi. Dalam teori komunikasi dikatakan,kejujuran adalah dasar dari komunikasi yang efektif dan hubungan yang sehat.

Kejadian yang menimpa dua anak manusia dalam cerita tersebut memberikan pelajaran kepada masyarakat Tehua terutama generasi muda untuk selalu mengedepankan sikap kejujuran dalam setiap perilaku hidup sehari-hari.

\subsection{Nilai Hubungan Manusia dengan Alam}

Alam dalam kehidupan manusia menempati posisi yang sangat penting karena keduanya tak dapat dipisahkan. Alam dan manusia memiliki hubungan erat selama dunia ini masih ada. Tanpa alam manusia tak dapat menikmati hidup.Alam menyediakan segalanya buat manusia. Alam adalah realitas kekuasaan Tuhan karena dengannya manusia diajarkan untuk mengenal akan kekuasaan dan kebesaran-Nya. Dalam beberapa ayat Al-Qur'an, Tuhan berfirman kepada hamba-Nya dengan kalimat "wamin aayatihi" (dan diantara tanda kekuasaan kami) merupakan sebuah pernyataan kepada manusia, "Jika mau mengetahui kekuasaan dan kebesaran-Ku maka lihatlah alam yang terbentang di sekelilingmu."

Namun sungguh ironis, hubungan antara keduanya mulai renggang. Eksploitasi hutan dengan dalih pemerataan pembangunan semakin gencar dilakukan. Hutan menjadi kering, tandus dan debit air makin menipis.

Ketika hutan digunduli, resapan air berkurang, terjadilah banjir dan tanah longsor. Yang merasakan akibatnya adalah manusia. Disinilah, titik inti dari makna hubungan antara keduanya; manusia dengan alam. Manusia membutuhkan alam, alam pun membutuhkan manusia. Ada hubungan simbiosis mutualis antara keduanya.

Kutukan yang diterimasepasang anak manusia tersebut mengandung makna bahwa ketika manusia telah serakah mengeskploitasi alam tanpa batas, maka bencana pasti akan terjadi. Dalam pandangan tradisional, alam pun dapat murka jika manusia tidak lagi mampu menjaganya.

Nilai ini penting ditanamkan kepada anak sebagai generasi pelanjut kehidupan orang tua agar suatu masa nanti anak tersebut mampu mengaktualisasikan dalam tiap gerak kehidupannya.

\subsection{Nilai Tanggung Jawab}

Setiap manusia diberi hak dan tanggung jawab, di mana hak dan tanggungjawab itu digunakan demi kemaslahatan diri dan orang lain. Tanggung-jawab adalah sikap mulia. Sikap ini dipandang member play effect (dampak baik) kepada manusia dalam mengarungi perjalanan hidupnya.Tanpanya, 
manusia kering dari nilai.Tuhan mengamanahi khalifah kepada manusia di muka bumi adalah bentuk pemberian tanggung jawab untuk mengurus, menjaga dan melestarikannya. Dengan akal, manusia dianggap mampu menjalankan tanggung jawab itu. Inilah nilai kemanusiaan manusia.

Namun sayang, sikap tanggung jawab dalam pergulatan zaman dewasa ini mulai luntur bahkan hilang sama sekali.Apriori terhadap sikap tanggung jawab semakin mengemuka. Manusia selalu mengabaikan tanggung jawab ketika diberi amanah, dan lari dari kenyataan ketika berhadapan dengan suatu masalah.

Nilai tanggung jawab membuat seseorang berwibawa, memiliki ketahanan diri dan memiliki etika. Maka nilai tanggung yang diisyaratkan dalam legenda WSM ini hendaknya dilestarikan sebagai sebuah sikap mulia, pendeknya berani berbuat, berani pula bertangungjawab.Karakter tokoh dalam cerita ini menunjukkan sikap yang jauh dari rasa tanggung jawab. Gadis ini tidak berani mempertanggungjawabkan perbuatannya, malah mengelak.

Pesan filosofi yang tercermin dari sikap gadis ini bagi masyarakat Tehua adalah ditancapkannya sikap berani mengakui perbuatan sebagai implementasi dari sikap tanggung jawab.Jika seseorang lari dari tanggung jawab, maka akibat negatif yang ditimbulkan sangat besar. Fenomena perilaku korupsi, kolusi dan nepotisme (KKN)yang melanda negeri ini merupakan akibat dari penyelewengan tanggung jawab yang diberikan oleh negara kepada mereka yang notabenekaum terpelajar. Perilaku semacam inihendaknya menjadi pelajaran berharga bagi masyarakat.

Sikap dan nilai ini harus menjadi warisan termulia kepada generasi muda, ketimbang harta. Anak harus dididik menjadi pribadi yang mandiri dan bertanggung jawab. Dengan pendidikan karakter dan moral, anak mengenal sikap tanggung jawab itu dan mempraktekan dalam kehidupannya, baik kehidupan dalam keluarga atau pun dalam kehidupan sosialnya.

\section{PENUTUP}

Sastra adalah pengejawantahan dari semesta manusia. Artinya setiap karya sastra yang diciptakan adalah hasil imitasi manusia terhadap alam semesta yang kemudian diaplikasikan dalam bentuk daya imajinasi; kemampuan daya khayal yang tinggi. Begitu juga karya-karya sastra lisan yang lahir dan tumbuh di tengah masyarakat pendukungnya.

Setiap genre sastra lisan yang ada merupakan kreasi cipta para leluhur. Kemampuan para leluhur dalam berkreasi adalah buah dari olah rasa dan olah cipta. Dengan kata lain ada hubungan dealektis antara alam nyata dengan alam pikiran.

Ciri khas sastra lisan yang membedakannya dengan sastra tulis adalah pertama, proses penyebarannya yang tidak linear artinya bentuknya tidak selalu kaku; dapat berubah sesuai konteks. Kedua, konteks penuturannya selalu berkelindan dengan aspek-aspek adat dan budaya. Ketiga, pewarisannya berlangsung secara lisan dari setiap generasi dengan mengandalkan mulut, penciptanya bersifat anonim, artinya sudah tidak diketahui lagi siapa penciptanya.Ini sebabkan karena kelisanannya. Keempat, pemiliknya adalah masyarakat tradisional karena keberadaannya tak dapat dipisahkan dengan kehidupan masyarakat tradisional tersebut, dan kelima diakui sebagai milik kolektif masyarakat pendukungnya.

Sastra lisan yang ada di negeri Tehua sampai saat ini masih terpelihara, yang salah satunya adalah legenda Wae Susu Mujualu. Legenda ini mempunyai fungsi ganda bagi masyarakatnya. Selain sebagai sarana estetika dan alat legitimasi adat dan kebudayaan, legenda WSM juga memberi fungsi pendidikan (education).Legenda ini juga dapat dijadikan sebagai salah satu bahan ajar di sekolah dengan berbasis kearifan lokal. 
Setiap sastra lisan mengandung nilai budaya yang dapat memberi nilai tambah bagi kehidupan masyarakat pemiliknya. Nilai-nilai budaya tersebut mempunyai kedudukan yang strategis di tengah kehidupan masyarakat. Ada lima kedudukan nilai-nilai tersebut, yakni (1) sebagai penggerak ucapan, tindakan, perbuatan, dan perilaku manusia atau kelompok manusia, (2) sebagai pengendali ucapan, tindakan, perbuatan, dan perilaku manusia agar tidak dianggap sesat dan menyimpang dari norma, aturan, dan hukum yang berlaku di masyarakat, (3) sebagai proyeksi tujuan, harapan, cita-cita hidup manusia, (4) sebagai tolok ukur ucapan, tindakan, perbuatan manusia sebagai makhluk pribadi sosial dan sebagai hamba dari Khaliknya, (5) sebagai rujukan (acuan) ucapan, tindakan, perbuatan, dan perilaku manusia sebagai makhluk pribadi, sosial, dan sebagai hamba Khaliknya.

Kedudukan nilai-nilai budaya tersebut terjelma menjadi basis kearifan lokal (localwisdom) yang diyakini dapat membawa manfaat jika ditaati sekaligus membawa mudharat jika diabaikan.

Legenda ini mempunyai nilai-nilai budaya yang bermanfaat bagi kelangsungan hidup masyarakat negeri Tehua. Nilai-nilai tersebut berfungsi untuk menguatkan keyakinan akan kekuasaan Tuhan, dapat mengaktualisasikan sifat jujur dalam hidup bermasyarakat, lebih mengeratkan lagi hubungan manusia dengan alam, dan mengajarkan masyarakat tentang pentingnya memiliki sikap tanggung jawab.

\section{DAFTAR PUSTAKA}

Amir, A. 2013.Sastra Lisan Indonesia. Yogyakarta: CV Andi Offset.

Amir, H. 1991.Nilai-Nilai Etis dalam Wayang. Jakarta: Sinar Harapan.
Danandjaja, J. 2002. Folklor Indonesia (Ilmu Gosip, Dongeng, dan Lain-Lain). Jakarta: Grafiti Pres.

Endraswara, S. 2008. Metodologi Penelitian Sastra (Epistemologi, Model, Teori dan Aplikasi. Yogyakarta: Media Pressindo.

Hutomo, S. S. 1991. Mutiara Yang Terlupakan.Pengantar Studi Lisan. Surabaya: HISKI Komisariat Jawa Timur.

Koentjaraningrat.2002. Manusia dan Kebudayaan Indonesia. Jakarta: Djambatan.

Purwadi. 2009. Folklor Jawa. Yogyakarta: Pura Pustaka.

Ratna, N. K. 2011. Paradigma Sosiologi Sastra. Yogyakarta: Pustaka Pelajar.

Saryono,D. 1997."Representasi Nilai Budaya Jawa dalam Prosa Fiksi Indonesia" Disertasi Doktor, IKIP Malang.Tidak diterbitkan.

Sibarani, R. 2012. Kearifan lokal. Hakikat, Peran, dan Metode Tradisi Lisan. Jakarta: Asosiasi Tradisi Lisan.

Supratno, H. 2010. "Aktualisasi Nilai-Nilai Tradisi Lisan Berwawasan Kepulauan sebagai Model Pendidikan Karakter Bangsa." Makalah disampaikan pada Seminar Nasional HIMBASADI tanggal 23 November 2010 LPMP Provinsi Maluku, Ambon.

Sugiono. 2011. Metode penelitian kombinasi (Mixed Method). Bandung: Alfabeta.

Taum, Y.Y. 2011.Studi Sastra Lisan.Sejarah, Teori, Metode, dan Pendekatan Disertai Contoh Penerapannya. Yogyakarta: Lamalera. 